\title{
Queenship and Dynastic Loyalty \\ Queenship and the currency of arts patronage as propaganda at the early Stuart court
}

History determines that royal palaces are commissioned and owned by the monarch and James I is widely accepted as the client for the Banqueting House in Whitehall, London, with Inigo Jones, Surveyor of the King's Works, as his architect. However, Inigo Jones arrived at court in the service of the queen consort, Anna of Denmark. The building was designed to house the spectacular court masques that she had revived and presided over with Jones as the creator of extraordinary stage scenery, costumes and special effects. Anna of Denmark's agency, and the ways in which the ephemeral arts of theatre, music and dance could influence and reflect court politics are now as invisible as the seventeenth-century brick core behind the stonework of the Banqueting House elevations. Nevertheless, these hidden histories are as integral to the building's purpose and importance as its masonry structure.

The Banqueting House has an iconic status as an architectural jewel and a monument to the Stuart dynasty. It was one of the most influential buildings in England when it was first completed in 1622 and it is justifiably celebrated as an Inigo Jones masterpiece, "the first truly Palladian building to go up in England."1 Only a handful of buildings by Jones have survived and the Banqueting House may be seen to have established the creative role of the architect in England as an artist, in the Renaissance sense of the word. It is revered by designers and architectural historians. Successive generations of leading architects have repaired and adapted the fabric of the building as a consequence of its prominence and its ownership by the Crown. Sir Christopher Wren adapted the interior after the Great Fire of London to provide a much-needed chapel. Sir John Soane replaced the roof and recreated the crumbling stone façade in the nineteenth century. James Wyatt respectfully substituted an annex at the north end of the building to house a new staircase. The building is still owned by the Crown and today it is managed as a heritage site by Historic Royal Palaces. Its layers of architectural significance have been meticulously analysed and explored through aboveground archaeology and archival research to support the conservation of the building as it approaches its 400 year anniversary ${ }^{2}$. Alongside these material investigations the historiography of the building has been reconsidered. Innovative digital interpretations have represented some of the lost histories of the building, locating it as the last surviving element of the great Tudor Palace of Whitehall. ${ }^{3}$ As a monument to vanished and transgressive histories it offers further avenues for research and interpretation.

As works of art, buildings and their interiors can serve as emotional and intellectual gateways to the multiple narratives that help us to understand the present through an analysis of the past. Palaces, in particular, hold a place in the public imagination and that position can change dramatically in response to current events. Kensington Palace, for example, served as a vessel for the nation's grief after the death of Diana, Princess of Wales, in 1987. The gilded 
palace gates and the ocean of bouquets banked up against them became an emotionally charged interface between the monarchy and the populace. A similarly spontaneous and overwhelming public engagement occurred in 2014 in response to Historic Royal Palaces' Blood Swept Lands and Seas of Red installation at the Tower of London. Again it was the cumulative effect of ordinary people coming, quite literally in their millions, that created an extraordinary phenomenon in which ritual and propaganda combined with a creative installation to satisfy a national desire to mark the centenary of the outbreak of the First World War. Images of Queen Elizabeth II in a moat filled with thousands of poppies, each representing a life lost in battle, were beamed around the world and they chimed with a public consciousness of her role, throughout her long reign, as the nation's leader in Remembrance Day ceremonies. The Tower of London, with its thousand-year history as a fortress, an armoury and a royal palace, became a monument not only to the First World War, but to all wars. Its significance, as an iconic building, flexed and metamorphosed into something new.

That fluid relationship between the iconic power of royal palaces and the nation's memory, its sense of its own identity, is particularly pertinent to the narratives that the Banqueting House represents. It was designed as visual propaganda amidst the preparations for a controversial European union. Protracted political negotiations for the marriage of Prince Charles to the Infanta of Spain appeared to be poised on the brink of success when the first Stuart banqueting house burned to the ground in January 1619. Its replacement was immediately authorised as an elegant addition to the Tudor Palace of Whitehall. More than double the size of the great hall there, it was designed as a magnificent venue for wedding festivities which would draw together royal guests from the great powers of Europe and beyond. ${ }^{4}$ Its Classical vocabulary and its location at the interface between the enclosed palace courtyards and Tudor apartments, and the public thoroughfare that is now Whitehall, evoked memories of an earlier, ephemeral structure on that same site. Queen Elizabeth I entertained the Duke of Anjou and his Embassy in a spectacular banqueting house constructed, according to the chronicles, in just three weeks and three days less than forty years earlier on the footprint of Jones's building. ${ }^{5}$ If history had taken a different turn it would have housed their wedding celebrations. Inigo Jones's design reflected the extravagant proportions and the swags of fruit and foliage that distinguished this Elizabethan banqueting house. But where the first structure on the site had been formed of 30 great masts, over 40 feet high, with canvas walls painted on the outside to look like stone and festooned with real pomegranates, grapes and other exotic fruit and vegetables, spangled with gold, Jones's designs were carved in stone.

The liminality of Jones's Banqueting House relates directly to its associations with queenship and marriage. Its decorative language and location bridges the Tudor and Stuart dynasties. Queen Anna of Denmark was the first queen consort in England since the death of Catherine Parr in 1548. Henry VIII's wives, after Katherine of Aragon, had been of noble rather than royal descent and Anna of Denmark was acutely aware of her independent authority as a 
royal princess. She was the daughter of King Frederick II of Denmark and the elder sister of his successor, Christian IV. In her gallery at Oatlands Palace her own full-length portrait hung alongside those of four Danish princes and, in an overt comparison, it was immediately adjacent to 'The picture of Queen Elizabeth'. ${ }^{6}$ Elizabeth's long reign, preceded by that of her half-sister Mary, had disrupted the conventions of queenship at the English court and Anna of Denmark, although consort rather than regnant, harnessed the legacy of these powerful queens and exerted her own influence through the arts. She recreated the role of queen consort. Many of her portraits, and those of her elder son Henry Frederick, were composed to invite comparison with images of their Tudor forbears. ${ }^{7}$ However, her patronage also promoted innovation and reflected a sophisticated dialogue with European courts.

Anna of Denmark was born in 1574 and spent her early childhood with her maternal grandparents in Güstrow in Germany, where she was joined by her brother Christian. ${ }^{8}$ She was 15 when she married James VI of Scotland and 28 when she was crowned Queen of England. Within a year she had revived and transformed the tradition of court masques as a vehicle for lavish spectacles in which she and her Ladies of the Bedchamber performed. ${ }^{9}$ The first of these, The Vision of the Twelve Goddesses, staged at Hampton Court Palace in January 1604, coincided with peace negotiations with Spain. Each taking the part of a goddess, the Queen and her Ladies were dressed in loose mantles and petticoats, recognisable to the court as having been made from 'embroidered satins and cloth of gold and silver, for which they were beholden to Queen Elizabeth's wardrobe. ${ }^{10}$ These classical goddesses descended from a mountain and made offerings at an altar in a Temple of Peace. Anna of Denmark represented Athena, the Greek goddess of wisdom and patron of the arts. The new Queen, restyling the garments of her predecessor, literally redressed old enmities between Britain and Spain. The goddesses then danced before the court and the Spanish and Polish Ambassadors, with the Queen's favourite, Lucy Harington, Lady Bedford, taking the Spanish Ambassador as her partner in a galliard. ${ }^{11}$

The designer for this first masque is unconfirmed but by the following year Inigo Jones had recently returned from Christian IV's court in Denmark and was established as the visual intelligence responsible for staging the Queen's masques. Jones had trained as a painter and his early travels are undocumented but they are believed to have included France, Germany and Italy before his arrival in Denmark in 1603 with the $5^{\text {th }}$ Earl of Rutland. ${ }^{12}$ Danish court culture at the affluent court of Christian IV was strongly influenced by that of the Imperial court in Prague and by the French 'ballet de cour' ${ }^{13}$ Jones's theatrical designs for Anna of Denmark may have signalled the alliance through marriage of their two countries, adapting the tradition of Elizabethan and Henrician court revels and masques to incorporate the Classical and international references of Danish visual culture. The Queen asserted her Danish identity and allegiances throughout her reign. Although she lacked the financial resources to emulate the scale of her brother's architectural patronage, the combined effect of her refurbishments at Somerset House, after it was designated for her use, with an elaborate 
court entertainment there in 1617 prompted the King to announce that henceforth it should be known as Denmark House. ${ }^{14}$

The Stuart court was polycentric. The court masques and royal celebrations for which Inigo Jones provided extravagant Classical guises and allusions brought together the distinct and at times divergent courts of the King, his Queen, and the Prince of Wales. Masque texts by Ben Jonson and others, which were published for greater dissemination, made topical references to the personalities and intrigues of court, most of which are now opaque. ${ }^{15}$ They enabled members of the royal family and their courtiers to assume the roles of goddesses and gods, of heroic mythological and fictional characters. In doing so they tested the boundaries between Absolute monarchy and divinity, between the representation of the Renaissance characteristics of princely rule and their personification. They also challenged constraints that prohibited female performance, effectively casting the most influential women at court on stage. Although there was a clear distinction between these courtly masquers who appeared as visions and danced, and more lowly professionals and musicians who sang and spoke, Anna of Denmark's masques further scandalised the faint hearted through their immodest costumes. ${ }^{16}$ The letter writer, John Chamberlain described the Queen's costume in The Vision of the Twelve Goddesses as 'not so much below the knee but that we might see a woman had both feet and legs, which I never knew before. 17

Portraits perpetuated and consolidated court memories of masques and their powerful messages. A painting of Lucy Harington, Countess of Bedford, in a masque costume by Inigo Jones celebrated her prestigious position at the Queen's court, dancing at her side in numerous early masques. ${ }^{18}$ It is believed to show her costume in Ben Jonson and Inigo Jones's masque, Hymenai, staged in 1606 to celebrate the wedding of Frances Howard to the Earl of Essex. Jonson described Jones's costumes as 'the most true impression of a celestial figure' but Harington's ankles, clad in orange stockings, were more earthly in their conspicuous exposure. ${ }^{19}$

Jonson and Jones collaborated on masque productions for the Stuart court for over twentyfive years. In spite of their famously disputatious relationship, their work spanned the courts of Anna of Denmark, James I and VI, and their sons, Henry and Charles. ${ }^{20}$ They established a distinctive aesthetic identity for the Stuart dynasty and, as two of the seventeenth-century's greatest creative forces, they ensured that the texts and designs for this obscure, elitist art form would be of enduring interest long after the political subtleties of their productions as commentaries on current affairs could been fully appreciated. Jones designed a Classical, triumphal arch and a great rock for the set of a spectacle by Ben Jonson when Christian IV arrived in England in July 1606 and rode with the King to be entertained at Theobalds. His experience as a theatrical designer, with its emphasis on dramatic effect and revelation, on buildings as backdrops and as sets against which the drama of monarchy could be played out, was fundamental to his creative development as an architect. He was a conjurer, creating 
visions and impressions. His Classical vocabulary became more assured after 1613 when he accompanied Princess Elizabeth (daughter of James I and Anna of Denmark) and her new husband through the courts of Europe to their new home in Heidelberg. He continued on to make an extended tour of Italy and to study the architecture of Andrea Palladio in the company of Thomas Howard, Earl of Arundel and his wife Alathea, one of Anna of Denmark's fellow masquers and closest companions.

One of Inigo Jones's accounts, presented after Anna of Denmark's death in March 1619, describes the breadth of her patronage with three quite separate and yet interconnected projects that he was designing concurrently for her in 1616. The Queen's House at Greenwich Palace and a Great Gate at her hunting palace in Surrey, Oatlands, both appropriated the visual - and European - language of Classicism. ${ }^{21}$ The third project was a masque at Denmark House for which the designs and text are now lost but it may be assumed that they projected the same Classical aesthetic. The Great Gate, too, is now lost but the account for the mason's work and a drawing by Jones both correlate with an accurate depiction of the gate in an innovative portrait of Anna of Denmark painted by Paul van Somer and dated $1617 .^{22}$ It marks the boundary between the Queen's hunting ground and the new vineyard and garden that she created at her Tudor palace. Inventories for Oatlands describe the painting hanging in one of two exquisitely furnished galleries that she refurbished there: 'In ye gallery next ye vineyard her Mats owne picture, wth her horse by her, done at large. ${ }^{23}$ It presents the Queen in hunting dress, fashionably styled with buttoned sleeves in homage to a Spanish vogue. An owl perched in the tree at her side references Minerva and her wisdom and enlightened patronage. As a satellite palace, the Queen entertained ambassadors at Oatlands and dined them in her galleries where paintings of Jupiter and ye gods feasting and Diana \& her maydes viewing their quarrey of red deere, hares, conyes etc reinforced the relationship between her Absolute status and the day's earthly activities. $^{24}$

The porosity of boundaries between divinity and royalty, between permanence and temporality is exemplified in the artistic culture of Anna of Denmark's court. Her interest in the material culture of Italy and the Continent signalled a more open exchange with political powers across the Channel. Classical mythology and extravagant spectacles performed for the King and court, for the most influential audience in the country, synthesised the performing arts with architecture and the rituals of monarchy. But they also codified the foreign policy that conflated international allegiances with royal marriage. Inigo Jones's design for the Banqueting House anticipated a union between England and Spain. It was the last building that he designed in Anna of Denmark's lifetime. She died in March 1619 before the plans were completed and the cost of her funeral, as a State occasion with a catafalque also designed by Jones, may have compromised the ambitions of his design. 
Prince Charles extended his mother's patronage of Jones and Jonson and became England's greatest royal collector. His 'marriage to Spain' was still in prospect when the Banqueting House opened with 'the Prince's Masque', The Masque of Augurs in 1622 and the following year the elevation for the building was used as a set for Ben Jonson's Time Vindicated to Himself and his Honours. It is also represented as a setting for a full-length portrait of James I by Paul van Somer. ${ }^{25}$ In the event, however, Charles married the French princess Henrietta Maria and another powerful queen consort, Marie de Medici, became his mother-in-law. The celebrated artist, Peter Paul Rubens completed the Marie de Medici cycle of twenty-four monumental, allegorical paintings exalting her life, and installed at the Palace of Luxembourg in time for their wedding, and in 1629 Rubens was commissioned to immortalize James I in the series of ceiling paintings for which the Banqueting House is now most renowned. The King is depicted grasping the arm of an allegory for Justice while the figure of Victory holds a wreath above his head and Jove's eagle transports him up to the heavens.

The power of material culture to epitomize the political and familial allegiances of its owners was not lost on Charles I's detractors. In 1643 the aptly-named Sir John Clotworthy MP marched with a troop of parliamentary soldiers to Somerset House where he forced entry into Queen Henrietta Maria's chapel and smashed a Rubens crucifixion to pieces with a halberd. As a vehement anti-papist he objected to the Queen's overt Catholicism but the Rubens also represented the elite extravagance and divine aspirations surrounding the royal family. The Banqueting House was consciously selected as the setting for Charles I's execution 6 years later and Rubens' ceiling would have been the last work of art that he looked upon before stepping out of the exquisitely proportioned Banqueting Hall onto a scaffold and his death. Inigo Jones lived to see the Banqueting House elevation appropriated by the Commonwealth as visual propaganda for their own cause. It was imaged again and again in popular prints and paintings as a backdrop to the bloody execution. The architectural details were corrupted and bastardised. The visual language that Jones had developed for the Stuart dynasty through his masque designs and costumes, his ceremonial gateways and buildings, and the paintings by van Somer and Rubens that had brought an international sophistication to the service of the English Crown, had not been lost on the populace. In every one of those prints and paintings the set for the King's execution was unmistakably Classical.

\footnotetext{
${ }^{1}$ Roy Strong, The English Icon: Elizabethan and Jacobean Portraiture (London: Routledge \& Kegan Paul Ltd., 1969), 57.

2 Jane Spooner, “The Banqueting House, Whitehall: Conservation Management Plan," (internal report, Historic Royal Palaces, 2015). Simon Thurley, Whitehall Palace. An Architectural History of the Royal Apartments, 1240-1698 (New Haven and London: Yale University Press in association with Historic Royal Palaces, 1999), 82.

${ }^{3}$ Adrian Murphy, "The Lost Palace: using technology to create a previously impossible visitor experience," Museums \& Heritage Advisor, 17 December 2015, www.advisor.museumsandheritage.com/features/the-lostpalace-using-technology-to-create-a-previously-impossible-visitor-experience/ (accessed June 2017).
} 


\footnotetext{
${ }^{4}$ See Simon Thurley, Whitehall Palace. An Architectural History of the Royal Apartments, 1240-1698 (New Haven and London: Yale University Press in Association with Historic Royal Palaces, 1999), 82.

${ }^{5}$ R. Holinshead, The Third Volume of Chronicles (1587), quoted in Howard Colvin, ed., The History of the King's Works, Vol.IV, 1485-1660, Part II (London: Her Majesty's Stationary Office, 1982), 320.

${ }^{6}$ East Sussex Record Office, Glynde MS 320.

${ }^{7}$ Wendy Hitchmough, "'Setting' the Stuart Court: Placing Portraits in the 'Performance' of Anglo Spanish Negotiations," submitted to Journal of British Art Studies, 4th Issue, 2016.

${ }^{8}$ See Leeds Barroll, Anna of Denmark, Queen of England. A Cultural Biography, (Philadelphia: University of Pennsylvania Press, 2001).

${ }^{9}$ Clare McManus (ed.), Women and Culture at the Courts of the Stuart Queens, (Basingstoke, Palgrave Macmillan, 2003); Clare McMnus, Women on the Renaissance Stage: Anna of Denmark and Female Masquing in the Stuart Court (1590-1619) (Manchester: Manchester University Press, 2002) 3.

${ }^{10}$ Dudley Carleton to John Chamberlain, 15 January 1604, Maurice Lee (ed.), Dudley Carleton to John Chamberlain 1603-1624 Jacobean Letters (New Brunswick: Rutgers University Press, 1972), 55.

${ }^{11}$ Ibid. See also Nadine Akkerman, "The goddess of the household: the masquing politics of Lucy HaringtonRussell, Countess of Bedford", Nadine Akkerman (ed.), The Politics of Female Households: Ladies-in-Waiting across Early Modern Europe (Leiden; Boston: Brill, 2014) 287-309.

12 John Harris, Stephen Orgel and Roy Strong, The King's Arcadia: Inigo Jones and the Stuart Court (London: Arts Council of Great Britain, 1973), 17.

${ }^{13}$ Lisbet Grandjean, "Christian IV and Drama," Council of Europe. European Art Exhibition 1988: Denmark, Christian IV and Europe: The $19^{\text {th }}$ Art Exhibition of the Council of Europe, (Kobenhavn: Foundation for Christian IV 1988), 142.

${ }^{14}$ Simon Thurley, Somerset House: The Palace of England's Queens 1551-169, (London: London Topographical Society, 2009), 36. John Chamberlain to Dudley Carleton, 8 March 1616/17, “The king dined that day with the queen at Somerset house, which was then new christned and must hence forward be called Denmark house", Calendar State Papers Domestic, 1611-18, 422, 514.

${ }^{15}$ David Lindley, ed., Court Masques: Jacobean and Caroline Entertainments, 1605-1640 (Oxford: Oxford University Press, 1995). See also James Knowles, “Introduction: 'Friends of All Ranks'? Reading the Masque in Political Culture" in James Knowles, Politics and political culture in the Court Masque (Basingstoke, Hampshire: Palgrave Macmillan, 2015) 1-20.

${ }^{16}$ Clare McManus, "When Is a Woman Not a Woman? Or, Jacobean Fantasies of Female Performance (16061611)", Modern Philology, Vol.105, No.3 (February 2008), 437-474.

${ }^{17}$ Dudley Carleton to John Chamberlain, 15 January 1704, Maurice Lee (ed.), Dudley Carleton to John Chamberlain 1603-1624 Jacobean Letters (New Brunswick: Rutgers University Press, 1972), 55.

${ }^{18}$ Attributed to John de Critz, Lucy Harington, Countess of Bedford, undated, 213.4 x $129.5 \mathrm{~cm}$, The Duke of Bedford, Woburn Abbey, reproduced in Stephen Orgel and Roy Strong, Inigo Jones and the Theatre of the Stuart Court, (London: Sotheby Parke Bernet Publications Ltd, 1973) 104.

${ }^{19}$ Stephen Orgel and Roy Strong, Inigo Jones and the Theatre of the Stuart Court, (London: Sotheby Parke Bernet Publications Ltd, 1973) 111.

${ }^{20}$ See Stephen Orgel and Roy Strong, Inigo Jones and the Theatre of the Stuart Court, (London: Sotheby Parke Bernet Publications Ltd, 1973) 2-3; D.J. Gordon, "Poet and Architect", Journal of the Warburg and Courtauld Institutes XII, (1949): 152-78

${ }^{21}$ The National Archives (London), 351/3389

${ }^{22}$ Paul van Somer, Anne of Denmark, 1617, 265.5 x 209 cm, Royal Collection Trust, RCIN 405887, and Inigo Jones, 'Oatlands Palace, Weybridge, Surrey: design for gateway to the vineyard', Royal Institute of British Architects, RIBA22803.

${ }^{23}$ East Sussex Record Office, Glynde MS 320.

${ }^{24}$ An Inventory of hir Mats owne stuffe in Oatelands taken ye day after her remove from there being the $7^{\text {th }}$ of October 1617, East Sussex Record Office, Glynde MS 320.

${ }^{25}$ Paul van Somer, James I and VI, c.1620, 227 x $149.5 \mathrm{~cm}$, Royal Collection Trust, RCIN 404446.
} 